\title{
Impact of foliar fertilization with nanosized zinc hydroxy nitrate on maize yield and quality
}

\author{
Krasimir Ivanov ${ }^{1 *}$, Tonyo Tonev ${ }^{2}$, Nguyen Nguyen ${ }^{1}$, Alexander Peltekov', Anyo Mitkov ${ }^{2}$ \\ Department of Chemistry, ${ }^{1}$ Agricultural University - Plovdiv, 12 Mendeleev St., 4000 Plovdiv, Bulgaria. Department of Farming and Herbology, \\ ${ }^{21}$ Agricultural University - Plovdiv, 12 Mendeleev St., 4000 Plovdiv, Bulgari
}

\section{A B S T R A C T}

\begin{abstract}
The objective of this study was to investigate the impact of foliar zinc application in the form of zinc hydroxy nitrate suspensions on maize grain yield and quality and on zinc distribution in the plant organs. The preparation of the zinc hydroxide nitrate $\left(\mathrm{Zn}_{5}(\mathrm{OH})_{8}\left(\mathrm{NO}_{3}\right)_{2} \cdot 2 \mathrm{H}_{2} \mathrm{O}\right)$ was performed by pouring a $\mathrm{NaOH}$ solution into $\mathrm{Zn}\left(\mathrm{NO}_{3}\right)_{2} \cdot 6 \mathrm{H}_{2} \mathrm{O}$ under vigorous stirring. All samples were characterized in detail by $\mathrm{X}$-ray diffraction, scanning electron microscopy, thermal analysis, and inductively coupled plasma (ICP) mass spectrometry to determine their content, morphology and physicochemical properties. The field experiment was conducted at the Research Farm, Agricultural University, Bulgaria, via a randomized block design with eight variants in 3 replications. A significant $(p<0.05)$ effect on $\mathrm{Zn}$ accumulation in the maize stems and leaves by foliar zinc application during the first growth stage was found. The accumulation of zinc was followed by its remobilization from the stems to other plant organs during the second growth stage. It was concluded that the synthesized zinc hydroxy nitrate has potential as a long-term foliar fertilizer. Ensuring the optimal concentration of $\mathrm{Zn}$ at different times during the vegetative period lead to a substantial increase in the grain yield along with an improvement in the quality of the corn grain for all variants compared to those of the control.
\end{abstract}

Keywords: Foliar fertilizers; Zinc fertilizers; Zinc hydroxy nitrate

\section{INTRODUCTION}

The healthy development of plants requires the absorption of sufficient amounts of macro- and microelements, and deficiencies in these nutrients have a significant impact on the quantity and quality of plant production. Zinc $(\mathrm{Zn})$ is one of the eight microelements (along with manganese, copper, boron, iron, zinc, chlorine, molybdenum and nickel) that are essential for normal and healthy plants and plant reproduction. The mean $\mathrm{Zn}$ concentration in plant tissues is in the range of 15-80 mg. $\mathrm{kg}^{-1}$ (Marschner, 1997). Its physiological role in plants is associated with its participation in many enzyme systems (carbonic anhydrase, superoxide dismutase, dehydrogenases), the activation of many other enzyme systems, protein synthesis, the integration of cell membranes, etc. (Alloway, 2008). A $\mathrm{Zn}$ deficiency in plants causes a number of structural and functional disorders such as increased membrane permeability, a high concentration of active oxygen forms, a reduced photosynthetic rate, and growth restriction, etc.

A zinc-deficient diet is also a significant problem for human health, which affects more than $1 / 3$ (one third) of the population on Earth (Zou, 2012). This problem can be partially resolved by increasing the zinc content in basic food products, such as grain and fruit crops, vegetables, etc., through the use of zinc-containing fertilizers that increase the zinc content in the final product without damaging its quality and yield and in most cases leads to a larger profit (Kanwal et al., 2010; Queiro et al., 2011).

Deficiencies in mineral elements in plants can be a consequence of several factors: an insufficient content in the soil, significant exports during plant production, and negative impacts of various factors on their mobile forms in the soil and their uptake by the plants (Sadeghzadeh, 2013). Correcting this deficiency is achieved through soil fertilization. In some cases, such as when there is a high $\mathrm{pH}$, a high carbonate content, an insufficient organic matter content, a lack of water and other factors in the soil that reduce the mobility of the elements, soil minerals are not efficiently taken up by plants. In these cases, the providing plants with microelements, including $\mathrm{Zn}$, can be accomplished through leaf fertilization (Li et al., 2016).

\footnotetext{
${ }^{*}$ Corresponding author:

Krasimir Ivanov Department of Chemistry, Agricultural University - Plovdiv, 12 Mendeleev St., 4000 Plovdiv, Bulgaria.

E-mail: kivanov1@abv.bg
}

Received: 02 March 2019; Accepted: 18 July 2019; 
Alleviating zinc deficiency usually is achieved through leaf fertilizers, which are often in the form of soluble zinc salts, mainly zinc sulphate and zinc oxide (Cakmak, 2009, Fernánez, et al. 2013). A significant disadvantage of soluble inorganic species, including the use of elements in their chelated form, is the risk of phytotoxicity. This disadvantage necessitates repeated plant treatment (2 - 4 sprays) with low concentrations during intensive growth to provide the necessary amount of nutrients. In recent years, zinc oxide ( $\mathrm{ZnO})$ has been extensively used as a slow-acting soil and leaf zinc fertilizer. A disadvantage of zinc oxide is its very low solubility in water $(3.0 \mathrm{mg} / \mathrm{l})$, which prevents its effective and rapid absorption by plants, as well as the uneven distribution of the suspension on the leaf surface (Fageria, et al. 2009, Singh, 2013).

The disadvantages of highly soluble inorganic salts and the poorly soluble oxides can be eliminated by the use of leaf nanofertilizers in which the nutrients are in the form of particles smaller than $100 \mathrm{~nm}$. There is a commercial product (Zintrac, 700) that consists of a slow-acting foliar fertilizer with a high zinc content of $700 \mathrm{~g} \mathrm{l}^{-1}$ and excellent physicochemical characteristics (crystal size from 50 to $100 \mathrm{~nm}$, stable suspension and easy application). The main disadvantages of the product are the low solubility of $\mathrm{ZnO}$ and the inability to quickly feed the plants zinc at specific stages in their development.

An alternative to the zinc fertilizers used in practice may be complex zinc salts with a better solubility than zinc oxide and significantly less solubility than ordinary inorganic zinc salts. They can be used as slow-acting leaf fertilizers that protect plants from phytotoxicity and provide a sufficient amount of the element for healthy plant growth. The most suitable of these types of fertilizers are zinc hydroxy nitrates and, in particular, zinc hydroxy nitrate with the following composition: $\mathrm{Zn}_{5}(\mathrm{OH})_{8}\left(\mathrm{NO}_{3}\right)_{2} \cdot 2 \mathrm{H}_{2} \mathrm{O}$ (Li et al., 2014). Its synthesis is well described in the scientific literature (Li et al., 2012; Newman and Jones, 1999), but its preparation in a form suitable for leaf fertilization has not yet found. Zinc hydroxy nitrate can be obtained in the form of plates with dimensions typically between 500 and $1800 \mathrm{~nm}$ wide and less than $100 \mathrm{~nm}$ thick (most often $20-80 \mathrm{~nm}$ ), allowing it to be retained on the surface of the leaves. Its solubility in water $\left(37.16 \mathrm{mg} \mathrm{l}^{-1}\right)$ allows plants to be fed with a sufficient amount of zinc without the risk of phytotoxicity.

The objective of this study was to investigate the impact of foliar zinc application in the form of zinc hydroxy nitrate suspensions on maize grain yield and quality and on zinc distribution in the plant organs.

\section{MATERIALS AND METHODS}

\section{Synthesis of ZnHN}

The preparation of the zinc hydroxide nitrate $\left(\mathrm{Zn}_{5}(\mathrm{OH})_{8}\left(\mathrm{NO}_{3}\right)_{2} \cdot 2 \mathrm{H}_{2} \mathrm{O}\right)$ was performed by pouring a $\mathrm{NaOH}$ solution into $\mathrm{Zn}\left(\mathrm{NO}_{3}\right)_{2} \cdot 6 \mathrm{H}_{2} \mathrm{O}$ under vigorous stirring, following Ivanov et al. 2017. All samples were characterized in detail by X-ray diffraction, scanning electron microscopy, thermal analysis, and inductively coupled plasma (ICP) mass spectrometry to determine their content, morphology and physicochemical properties.

\section{Field experiment}

The field experiment was conducted at the Research Farm, Agricultural University, Bulgaria, via a randomized block design with eight variants in 3 replications. The size of the harvesting plots was $20 \mathrm{~m}^{2}$, and the number of plants/plot was $133 \pm 2$ (Fig. 1).

The base fertilization (NPK 15:15:15, $5.0 \mathrm{~kg}^{-1}$ ) and drip irrigation were the same for all variants. The hybrid $\mathrm{Pr}$ 9241, group 370 according to the FAO, was chosen for the experiment, given its excellent qualities (high ecological flexibility) and acclimatization to the area of research.

Before planting, surface soil samples $(0-20 \mathrm{~cm}$ depth) from each harvesting plot were collected, mixed, air dried and analysed for the selected physicochemical properties in the university laboratory, which is accredited under BDS EN ISO 17025/2006 for soil and plant analyses. The results are presented in Table 1 .

The soil in this research area was alluvial with a highly alkaline $\mathrm{pH}(8.20)$ and low content of organic matter. It is characterized by a low content of available $\mathrm{Ca}, \mathrm{Cu}, \mathrm{Mn}$, and $\mathrm{Fe}$ and a medium content of available N, P and $\mathrm{K}$ and $\mathrm{Mg}$ compared to the average content of these elements in Bulgarian soils. The content of available $\mathrm{Zn}$ is less than $3.0 \mathrm{mg} \mathrm{kg}^{-1}$ and can be classified as low according to the MAAF 1998 classification (Papadopoulos et al., 2009).

Eight suspension solutions with different $\mathrm{Zn}$ concentrations were used in our experiment (Table 2), including a commercial $\mathrm{ZnO}$ suspension $(\mathrm{CmZnO}, 1 \mathrm{~A}$

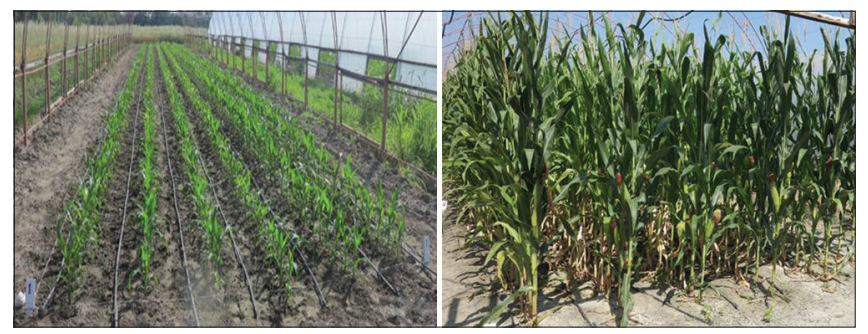

Fig 1. Pictures of the corn plants at the beginning and end of the experiment. 
and $1 \mathrm{~B}$ ), containing $70 \% \mathrm{Zn}$, and suspensions synthesized by us with $\mathrm{ZnHN}$ alone (2A and $2 \mathrm{~B}$ ) or mixed with $\mathrm{Zn}\left(\mathrm{NO}_{3}\right)_{2}$ (3A and 3B) or organic materials, containing $44 \%$ dry matter (organic compounds $82 \%$, including 35\% monoacids, 3.8\% total nitrogen, 3\% total phosphorus as $\mathrm{P}_{2} \mathrm{O}_{5}$ and $4 \%$ potassium as $\mathrm{K}_{2} \mathrm{O}$ ) (4A and $4 \mathrm{~B}$ ). The eight variants were divided into two groups. The first group included the variants in which the $\mathrm{Zn}$ content in the applied foliar fertilizer was $350 \mathrm{~g} \mathrm{ha}^{-1}$ (variants $1 \mathrm{~A}-4 \mathrm{~A}$ ), and the second group included the variants in which the $\mathrm{Zn}$ content in the applied foliar fertilizer was $700 \mathrm{~g} \mathrm{ha}^{-1}$ (variants $1 \mathrm{~B}-4 \mathrm{~B})$.

After harvesting, the cobs were air dried and weighed. Random samples of grain were milled, mixed and analysed for zinc, dry matter, nitrogen, phosphorus, potassium, protein, fat, starch and micro - and macroelements $(\mathrm{Cu}$,

Table 1: Soil properties and total and available $\mathrm{Ca}, \mathrm{Mg}, \mathrm{Cu}, \mathrm{Fe}$ and $\mathrm{Zn}$ concentrations

\begin{tabular}{|c|c|c|}
\hline Soil test parameter & Test level & Test rating \\
\hline Soil pH (1:5) & $8.20 \pm 0,02$ & Alkaline \\
\hline Electrical conductivity $\left(\mu \mathrm{S} \mathrm{cm}^{-1}\right)$ & 300 & - \\
\hline Organic matter (\%) & $0.952(1.64)$ & Low \\
\hline \multicolumn{3}{|c|}{ Nutrients $\mathrm{mg} \mathrm{kg}^{-1}$} \\
\hline Nitrogen (available, 1,0\% KCl) & $42,65 \pm 2,10$ & Medium \\
\hline Potassium (EPA 3051) & $4320,2 \pm 27,4$ & Medium \\
\hline $\begin{array}{l}\text { Potassium } \\
\text { (available, } 2 \mathrm{~N} \mathrm{HCl})\left(\mathrm{K}_{2} \mathrm{O}\right)\end{array}$ & $205,74 \pm 7,43$ & Medium \\
\hline $\begin{array}{l}\text { Phosphorous }\left(\mathrm{P}_{2} \mathrm{O}_{5}\right) \\
\text { (available, laktaten) }\end{array}$ & $43.86 \pm 2,20$ & Medium \\
\hline Calcium (EPA 3051) & $432,20 \pm 2,76$ & Low \\
\hline Calcium (available, $1 \mathrm{~N} \mathrm{KCl}$ ) & $269.50 \pm 5.66$ & Low \\
\hline Magnesium (EPA 3051) & $4710 \pm 57,43$ & Medium \\
\hline Magnesium (available, $1 \mathrm{~N} \mathrm{KCl}$ ) & $128.75 \pm 4.54$ & Medium \\
\hline Copper (EPA 3051A) & $16,22 \pm 0,38$ & Medium \\
\hline Copper (available, DTPA) & $2.24 \pm 0,08$ & High \\
\hline Manganese (EPA 3051A) & $160.26 \pm 3.24$ & Medium \\
\hline Manganese (available, DTPA) & $13.84 \pm 0,30$ & High \\
\hline Iron (EPA 3051A) & $10970 \pm 270$ & Medium \\
\hline Iron (available, DTPA) & $7.40 \pm 0.06$ & Low \\
\hline Zinc (EPA 3051A) & $135 \pm 1,02$ & Low \\
\hline Zinc (available, DTPA) & $2.82 \pm 0.10$ & Low \\
\hline
\end{tabular}

$\mathrm{Fe}, \mathrm{Mg}, \mathrm{N}, \mathrm{P}, \mathrm{K}$ and $\mathrm{Ca}$ ). All samples were digested using a mixture of $\mathrm{HNO}_{3}$ and $\mathrm{H}_{2} \mathrm{O}_{2}$ in a MARS 6 - Microwave Digestion System - CEM Corporation.

The results obtained were analysed statistically using IBM SPSS statistic software.

No visible symptoms of zinc deficiency were observed throughout the growth period, both for the control and for all variants. No diseases or pests with an economically significant density were found.

\section{RESULTS}

Preparation and characterization of $\mathrm{Zn}_{5}(\mathrm{OH})_{8}\left(\mathrm{NO}_{3}\right)_{2} \cdot 2 \mathrm{H}_{2} \mathrm{O}$ Fig. 2a presents the X-ray pattern of $\mathrm{Zn}_{5}(\mathrm{OH})_{8}\left(\mathrm{NO}_{3}\right)_{2} \cdot 2 \mathrm{H}_{2} \mathrm{O}$ with an $\mathrm{OH} / \mathrm{Zn}$ molar ratio of 1.4 . The strongest peak at $2 \theta=9.2^{\circ}$ and other characteristic peaks at $2 \theta=18.4,34.6$, $35.4,46.8$, and $47.4^{\circ}$ indicated the formation of pure wellcrystallized zinc hydroxide nitrate $\left(\mathrm{Zn}_{5}(\mathrm{OH})_{8}\left(\mathrm{NO}_{3}\right)_{2} \cdot 2 \mathrm{H}_{2} \mathrm{O}\right.$, JCPDS card 24-1460).

Fig. $2 \mathrm{~b}$ presents the SEM images of some samples (OH/ $\mathrm{Zn}$ molar ratio 1.4). The sample was composed of sheetlike particles, which is the typical morphology of zinc hydroxide nitrate.

More details on the $\mathrm{Zn}_{5}(\mathrm{OH})_{8}\left(\mathrm{NO}_{3}\right)_{2} \cdot 2 \mathrm{H}_{2} \mathrm{O}$ synthesis, content, morphology and physicochemical properties are described elsewhere (Ivanov et al. 2017).

\section{Impact of foliar fertilization on the zinc distribution in the maize organs}

The foliar fertilizer was applied twice during the growth period. The first spraying was carried out at the end of May (5 - 6 fully emerged leaf), and the second spraying was carried out at the end of June (10 - 11 fully developed leaf). Twenty days after each spraying, random composite samples (roots, shoots and leaves) were collected and analysed for zinc content after drying for $12 \mathrm{~h}$ at $85^{\circ} \mathrm{C}$.

Table 2: Scheme of the experiment

\begin{tabular}{|c|c|c|c|c|}
\hline \multicolumn{5}{|l|}{ Variants } \\
\hline Control & $1 \mathrm{~A}$ & $2 \mathrm{~A}$ & $3 \mathrm{~A}$ & 4A \\
\hline & $\begin{array}{l}\text { CmZnO suspension } \\
\mathrm{Zn}-1.75 \mathrm{~g} \mathrm{l}^{-1} \\
\text { Total } \mathrm{Zn}-0.70 \mathrm{~g} / \text { plot }\end{array}$ & $\begin{array}{l}\text { ZnHN suspension } \\
\mathrm{Zn}-1.75 \mathrm{~g} \mathrm{l}^{-1} \\
\text { Total } \mathrm{Zn}-0.70 \mathrm{~g} / \text { plot }\end{array}$ & $\begin{array}{l}\text { ZnHN suspension } \\
\mathrm{Zn}-1.55 \mathrm{~g} \mathrm{l}^{-1} \\
\mathrm{Zn}(\mathrm{NO} 3) 2 \text { solution } \\
\mathrm{Zn}-0.20 \mathrm{~g} . \mathrm{l}-1 \\
\text { Total } \mathrm{Zn}-0.70 \mathrm{~g} / \mathrm{plot}\end{array}$ & $\begin{array}{l}\text { ZnHN suspension } \\
\mathrm{Zn}-1.75 \mathrm{~g} \mathrm{l}^{-1} \\
\text { Total } \mathrm{Zn}-0.70 \mathrm{~g} / \text { plot } \\
\text { Organics } \\
2.0 \mathrm{~g} \mathrm{l}-1\end{array}$ \\
\hline \multirow[t]{2}{*}{ Control } & 1B & 2B & 3B & 4B \\
\hline & $\begin{array}{l}\text { CmZnO suspension } \\
\mathrm{Zn}-3.50 \mathrm{~g} \mathrm{l}^{-1} \\
\text { Total } \mathrm{Zn}-1.40 \mathrm{~g} / \text { plot }\end{array}$ & $\begin{array}{l}\text { ZnHN suspension } \\
\mathrm{Zn}-3.50 \mathrm{~g} \mathrm{l}^{-1} \\
\text { Total } \mathrm{Zn}-1.40 \mathrm{~g} / \text { plot }\end{array}$ & $\begin{array}{l}\text { ZnHN suspension } \\
\mathrm{Zn}-3.50 \mathrm{~g}^{-1} \\
\mathrm{Zn}(\mathrm{NO}) 2 \text { solution } \\
\mathrm{Zn}-0.40 \mathrm{~g} \mathrm{l}^{-1} \\
\text { Total } \mathrm{Zn}-1.40 \mathrm{~g} / \mathrm{plot}\end{array}$ & $\begin{array}{l}\text { ZnHN suspension } \\
3.50 \mathrm{~g} \mathrm{l}^{-1} \\
\text { Total Zn-1.40 g/plot } \\
\text { Organics } \\
4.0 \mathrm{~g} \mathrm{l}^{-1}\end{array}$ \\
\hline
\end{tabular}




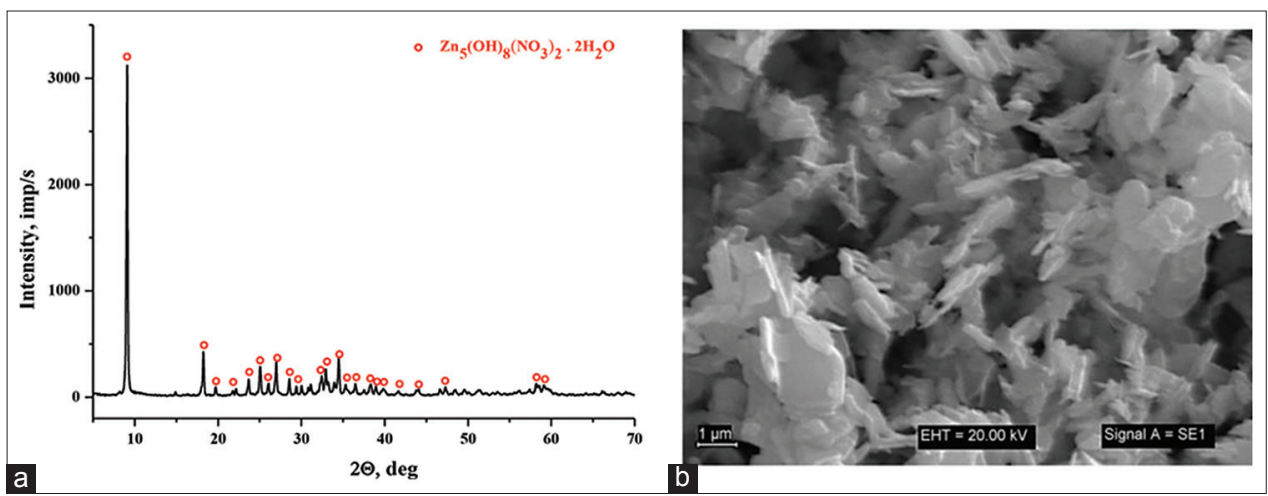

Fig 2. X-ray pattern (a) and SEM image (b) of the sample synthesized at $25^{\circ} \mathrm{C}$ and a $\mathrm{OH} / \mathrm{Zn}$ molar ratio of 1.4.

Table 3 presents the zinc concentrations in the maize organs three weeks after the first spraying.

The content of zinc in the roots varied within a relatively narrow range of 15.62 for the control sample to $19.34 \mathrm{mg} \mathrm{kg}^{-1}$ for variant 4 , with the mean value for all variants being $17.45 \pm 1.11 \mathrm{mg} \mathrm{kg}^{-1}$. The zinc content in the stems ranges widely from 21.04 in the control sample to $44.92 \mathrm{mg} \mathrm{kg}^{-1}$ in variant $2 \mathrm{~B}$, and the mean value for all variants was $37.07 \pm 4.84 \mathrm{mg} \mathrm{kg}^{-1}$. The difference in the zinc content in the leaves was also significant. It ranged from 20.71 in the control sample to $32.74 \mathrm{mg} \mathrm{kg}^{-1}$ in variant $3 \mathrm{~B}$. The mean value for all variants was $27.28 \pm 3.02 \mathrm{mg} \mathrm{kg}^{-1}$.

Table 4 shows the zinc concentration in the maize organs three weeks after the second spraying.

The results for the zinc concentration in the maize organs three weeks after the second spraying were significantly different from those after the first spraying. The content of zinc in the plant roots increased by approximately two times and ranged from $33.24 \mathrm{mg} \mathrm{kg}^{-1}$ in variant $1 \mathrm{~B}$ to $36.75 \mathrm{mg} \mathrm{kg}^{-1}$ in variant $3 \mathrm{~A}$. The same tendency was observed in the leaves, where the zinc content varied from $29.7 \mathrm{mg} \mathrm{kg}^{-1}$ in the control to $48.71 \mathrm{mg} \mathrm{kg}^{-1}$ in variant 3B. Conversely, the content of zinc in the stems decreased considerably in both the control sample and the variants and ranged from $15.80 \mathrm{mg} \mathrm{kg}^{-1}$ in the control to $27.04 \mathrm{mg} \mathrm{kg}^{-1}$ in variant 3B.

\section{Impact of foliar fertilization on the grain yield and quality}

Table 5 presents the impact of $\mathrm{ZnHN}$ application on the grain yield.

The average yield from the three replicates for the control was $18.2 \mathrm{~kg} / 20 \mathrm{~m}^{2}$ (recalculated $9.10 \mathrm{t} \mathrm{ha}^{-1}$ ); the variants from the first group, $20.40 \mathrm{~kg} / 20 \mathrm{~m}^{2}$ (recalculated as $\left.10,20 \mathrm{t} \mathrm{ha}^{-1}\right)$; and the variants from the second group, $21.09 \mathrm{~kg} / 20 \mathrm{~m}^{2}$ (recalculated as $10.55 \mathrm{t} \mathrm{ha}^{-1}$ ).
Table 3: Zinc concentration in the plant tissue three weeks after the first spraying

\begin{tabular}{lccc}
\hline Variant & \multicolumn{3}{c}{ Zinc concentration in the maize organs, } \\
& Roots & Stems & Leaves \\
\cline { 2 - 4 } & $15.62 \pm 1.02$ & $21.04 \pm 1.00$ & $20.71 \pm 1.16$ \\
\hline Control & 16.04 & 30.82 & 23.14 \\
1A & 16.92 & 34.41 & 25.83 \\
1B & 19.34 & 36.93 & 27.45 \\
2A & 17.73 & 44.92 & 29.43 \\
2B & 17.05 & 39.24 & 28.76 \\
3A & 16.64 & 42.34 & 32.74 \\
3B & 18.80 & 32.45 & 24.62 \\
4A & 17.10 & 35.44 & 26.24 \\
4B & $17.45 \pm 1.11$ & $37.07 \pm 4.84$ & $27.28 \pm 3.02$ \\
Mean for variants &
\end{tabular}

${ }^{*}$ Data represent the mean $\pm \mathrm{SD}$ for the control and the mean of three independent replicates for all other variants.

Table 4: Zinc concentration in the plant tissue three weeks after second spraying

\begin{tabular}{lccc|}
\hline \multirow{2}{*}{ Variant } & \multicolumn{3}{c|}{ Zinc concentration, $\mathbf{~ m ~ k g}^{-1} \mathbf{~ d . ~ w t ~}$} \\
\cline { 2 - 4 } & Roots & Stems & Leaves \\
\hline Control & $33.80 \pm 1.04$ & $15.8 \pm 1.12$ & $29.7 \pm 2.46$ \\
1A & 35,62 & 19.53 & 36.55 \\
1B & 33,24 & 22.35 & 39.62 \\
2A & 35,43 & 24.14 & 42.93 \\
2B & 34,86 & 25.72 & 47.04 \\
3A & 36,75 & 26.76 & 46.73 \\
3B & 34,54 & 27.04 & 48.71 \\
4A & 35,92 & 24.63 & 40.04 \\
4B & 34,11 & 22.04 & 41.42 \\
Mean for variants & $35.06 \pm 1.11$ & $27.28 \pm 3.02$ & $42.88 \pm 4.25$ \\
\hline
\end{tabular}

${ }^{*}$ Data represent the mean $\pm \mathrm{SD}$ for the control and the mean of three independent replicates for all other variants.

Tables 6 and 7 present the impact of $\mathrm{ZnHN}$ application on the content of grain structural components and grain microelements.

The Dry matter and fat content varied within a narrow range of 85.63 to 86.68 and of 4.58 to 5.20, respectively, with no significant difference between the control sample and the variants $(\mathrm{p}<0.05)$. The nitrogen and protein 
Table 5: Impact of ZHN application on the grain yield (kernels and cob)

\begin{tabular}{|c|c|c|c|c|c|c|c|c|c|}
\hline \multirow[t]{2}{*}{ Grain yield } & \multirow[t]{2}{*}{ Control } & \multicolumn{4}{|c|}{ Variants, 350 g Zn ha $^{-1}$} & \multicolumn{4}{|c|}{ Variants, $700 \mathrm{~g} \mathrm{Zn} \mathrm{ha}^{-1}$} \\
\hline & & $1 \mathrm{~A}$ & $2 \mathrm{~A}$ & $3 \mathrm{~A}$ & $4 \mathrm{~A}$ & $1 \mathrm{~B}$ & 2 B & $3 \mathrm{~B}$ & $4 \mathrm{~B}$ \\
\hline \multirow{2}{*}{$\begin{array}{l}\mathrm{kg} / \\
20 \mathrm{M}^{2}\end{array}$} & 18.20 & 19.30 & 20.51 & 21.90 & 19.90 & 20.42 & 21.30 & 22.41 & 20.22 \\
\hline & & \multicolumn{4}{|c|}{ Average $20.40 \pm 1.11$} & \multicolumn{4}{|c|}{ Average $21.09 \pm 1.00$} \\
\hline \multirow[t]{2}{*}{ t.ha-1 } & 9.10 & 9.65 & 10.26 & 10.95 & 9.95 & 10.21 & 10.65 & 11.21 & 10.11 \\
\hline & & \multicolumn{4}{|c|}{ Average $10.20 \pm 0.56$} & \multicolumn{4}{|c|}{ Average $10.55 \pm 0.50$} \\
\hline \multirow[t]{2}{*}{${ }^{*} \Delta, \%$} & - & 6.04 & 12.75 & 20.33 & 9.34 & 12.20 & 17.03 & 23.19 & 11.10 \\
\hline & & \multicolumn{4}{|c|}{ Average $12.12 \pm 6.12$} & \multicolumn{4}{|c|}{ Average $15.88 \pm 5.51$} \\
\hline
\end{tabular}

*Differences between the yield of the control and yield of the variants in \%.

Table 6: Impact of ZHN application on the grain structural components

\begin{tabular}{|c|c|c|c|c|c|c|c|c|c|}
\hline \multirow{2}{*}{$\begin{array}{l}\text { Indicator, } \\
\%\end{array}$} & \multirow[t]{2}{*}{ Control } & \multicolumn{4}{|c|}{ Variants, 350 g Zn ha ${ }^{-1}$} & \multicolumn{4}{|c|}{ Variants, 700 g Zn ha-1 } \\
\hline & & $1 \mathrm{~A}$ & $2 \mathrm{~A}$ & $3 \mathrm{~A}$ & $4 \mathrm{~A}$ & $1 \mathrm{~B}$ & 2 B & $3 \mathrm{~B}$ & $4 \mathrm{~B}$ \\
\hline \multirow[t]{2}{*}{ Dry matter } & 86.58 & 86.16 & 85.63 & 85.29 & 86.12 & 85.88 & 86.68 & 86.19 & 86.22 \\
\hline & & \multicolumn{4}{|c|}{ Average $85.8 \pm 0.42$} & \multicolumn{4}{|c|}{ Average $86.24 \pm 0.08$} \\
\hline \multirow[t]{2}{*}{ Nitrogen } & 1.05 & 1.24 & 1.14 & 1.27 & 1,33 & 1,19 & 1.20 & 1.23 & 1.22 \\
\hline & & \multicolumn{4}{|c|}{ Average $1.25 \pm 0.08$} & \multicolumn{4}{|c|}{ Average $1.21 \pm 0.02$} \\
\hline \multirow[t]{2}{*}{ Protein } & 6.57 & 7.76 & 7.08 & 7.91 & 8,27 & 7,50 & 7.48 & 7,69 & 7.61 \\
\hline & & \multicolumn{4}{|c|}{ Average $7.76 \pm 0.50$} & \multicolumn{4}{|c|}{ Average $7.57 \pm 0.10$} \\
\hline \multirow[t]{2}{*}{ Fat } & 4.72 & 4.77 & 4.58 & 4.60 & 4,74 & 5,20 & 4.79 & 4,99 & 4.78 \\
\hline & & \multicolumn{4}{|c|}{ Average $4.67 \pm 0.10$} & \multicolumn{4}{|c|}{ Average $4.94 \pm 0.20$} \\
\hline \multirow[t]{2}{*}{ Starch } & 79.78 & 75.44 & 79.07 & 76.21 & 75,31 & 75.69 & 73.94 & 72.28 & 76.96 \\
\hline & & \multicolumn{4}{|c|}{ Average $76.51 \pm 1.75$} & \multicolumn{4}{|c|}{ Average $74.71 \pm 1.75$} \\
\hline \multirow[t]{2}{*}{ Phosphorus } & 0.24 & 0.26 & 0.20 & 0.17 & 0.17 & 0.22 & 0.20 & 0.17 & 0.18 \\
\hline & & \multicolumn{4}{|c|}{ Average $0.20 \pm 0.04$} & \multicolumn{4}{|c|}{ Average $0.19 \pm 0.02$} \\
\hline \multirow[t]{2}{*}{ Potassium } & 0.31 & 0.31 & 0.26 & 0.23 & 0.24 & 0.31 & 0.26 & 0.23 & 0.25 \\
\hline & & \multicolumn{4}{|c|}{ Average $0.26 \pm 0.04$} & \multicolumn{4}{|c|}{ Average $0.26 \pm 0.03$} \\
\hline
\end{tabular}

content increased significantly ( $p<0.05$ ), while the content of phosphorus and potassium decreased significantly $(\mathrm{p}<0.05)$.

The results in Table 7 show that the measured values for all elements are within the typical range for maize corn.

Contrary to our expectations, the zinc content of the maize grains varied within a narrow range, and there was no significant impact of $\mathrm{ZnHN}$ fertilization. The same trend can be seen for the $\mathrm{Cu}$ and $\mathrm{Mg}$ content. The results for iron were different. In this case, the impact of fertilization was significant and lead to an up to a 3 -fold decrease in the iron content in the maize grains.

\section{DISCUSSION}

According to Haslet et al. (2001), the knowledge on zinc transport in plants is inadequate. Some authors report that $\mathrm{Zn}$ can be transported in the phloem, while others claim that such transport does not occur. Despite many publications on the uptake of microelements by different plants, little is known about the transport of zinc from the leaves to other plant organs of maize. To obtain more information on this issue, we tracked the dynamics of zinc movement in the roots, stems and leaves of maize throughout the growing period. The results presented in Table 3 give describe low levels of zinc in the roots during the first stage of growth. This result can be explained by the low temperatures in April and early May (17.0 and $19.8^{\circ} \mathrm{C}$, respectively) and the poorly developed root system of the plants during this period. There was no statistically significant difference in the zinc content between the control sample and the variants at a significance level of $\mathrm{p}<0.05$. In contrast, the results for the zinc content in the stems of the plants were significantly higher than those in the roots. Apparently, this result is due to spraying the $\mathrm{ZnHN}$ suspension, which results in a statistically significant difference between the control sample and the variants at a significance level of $\mathrm{p}<0.05$.

Surprisingly, at this stage of the growth period, the content of zinc in the leaves was significantly less than that in the stems. This finding can be explained the fact that a substantial amount of the zinc permeated through the cuticle to the stem. Some of the zinc is retained in the leaves, which resulted in a statistically significant difference between the control sample and the variants at a significance level of $\mathrm{p}<0.05$.

The results in Table 4 show a significant increase in the content of zinc in the plant roots from $33.24 \mathrm{mg} \mathrm{kg}^{-1}$ in 
Table 7: Impact of ZnHN application on the content of the corn grain microelements.

\begin{tabular}{|c|c|c|c|c|c|}
\hline \multirow[t]{2}{*}{ Element, mg kg-1 } & \multirow[t]{2}{*}{ Control* $^{*}$} & \multicolumn{4}{|c|}{ Variants $175 \mathrm{~g} \mathrm{Zn} \mathrm{ha}^{-1}$} \\
\hline & & $1 \mathrm{~A}$ & $2 \mathrm{~A}$ & $3 \mathrm{~A}$ & $4 \mathrm{~A}$ \\
\hline \multirow[t]{2}{*}{$\mathrm{Zn}$} & $18.21 \pm 0.44$ & 18.93 & 17.46 & 17.8 & 19.20 \\
\hline & & \multicolumn{4}{|c|}{ Average for the variants $18.35 \pm 0.85$} \\
\hline \multirow[t]{2}{*}{$\mathrm{Cu}$} & $1.40 \pm 0.20$ & 1.30 & 1.55 & 1.35 & 1.82 \\
\hline & & \multicolumn{4}{|c|}{ Average for the variants $1.51 \pm 0.24$} \\
\hline \multirow[t]{2}{*}{$\mathrm{Ca}$} & $51.20 \pm 2.4$ & 55.95 & 40.5 & 41.25 & 39.1 \\
\hline & & \multicolumn{4}{|c|}{ Average for the variants $44,2 \pm 7.88$} \\
\hline \multirow[t]{2}{*}{$\mathrm{Mg}$} & $931.10 \pm 28.1$ & 887.6 & 760.5 & 716.1 & 916.0 \\
\hline & & \multicolumn{4}{|c|}{ Average for the variants $820.0 \pm 96.8$} \\
\hline \multirow[t]{2}{*}{$\mathrm{Fe}$} & $20.41 \pm 0.64$ & 13.50 & 8.41 & 6.70 & 7.82 \\
\hline & & \multicolumn{4}{|c|}{ Average for the variants $9.10 \pm 3.0$} \\
\hline \multirow[t]{2}{*}{ Element, mg kg-1 } & Control* $^{*}$ & \multicolumn{4}{|c|}{ Variants $350 \mathrm{~g} \mathrm{Zn} \mathrm{ha-1}^{-1}$} \\
\hline & & $1 \mathrm{~B}$ & $2 \mathrm{~B}$ & $3 \mathrm{~B}$ & $4 \mathrm{~B}$ \\
\hline \multirow[t]{2}{*}{$\mathrm{Zn}$} & $18.21 \pm 0.44$ & 17.72 & 18.23 & 18.48 & 18.10 \\
\hline & & \multicolumn{4}{|c|}{ Average for the variants $18.13 \pm 0.32$} \\
\hline \multirow[t]{2}{*}{$\mathrm{Cu}$} & $1.40 \pm 0.20$ & 1.31 & 1.55 & 1.70 & 1.85 \\
\hline & & \multicolumn{4}{|c|}{ Average for the variants $1.60 \pm 0.23$} \\
\hline \multirow[t]{2}{*}{$\mathrm{Ca}$} & $51.20 \pm 2.4$ & 53.65 & 50.15 & 41.45 & 39.15 \\
\hline & & \multicolumn{4}{|c|}{ Average for the variants $46.10 \pm 6.91$} \\
\hline \multirow[t]{2}{*}{$\mathrm{Mg}$} & $931.10 \pm 28.1$ & 990.60 & 745.24 & 748.14 & 804,12 \\
\hline & & \multicolumn{4}{|c|}{ Average for the variants $822.02 \pm 115.60$} \\
\hline \multirow[t]{2}{*}{$\mathrm{Fe}$} & $20.41 \pm 0.64$ & 14.00 & 6.50 & 7.41 & 9.72 \\
\hline & & \multicolumn{4}{|c|}{ Average for the variants $9.41 \pm 3.35$} \\
\hline
\end{tabular}

*Data represent the mean \pm SD for the control and the mean of three independent replicates for all other variants.

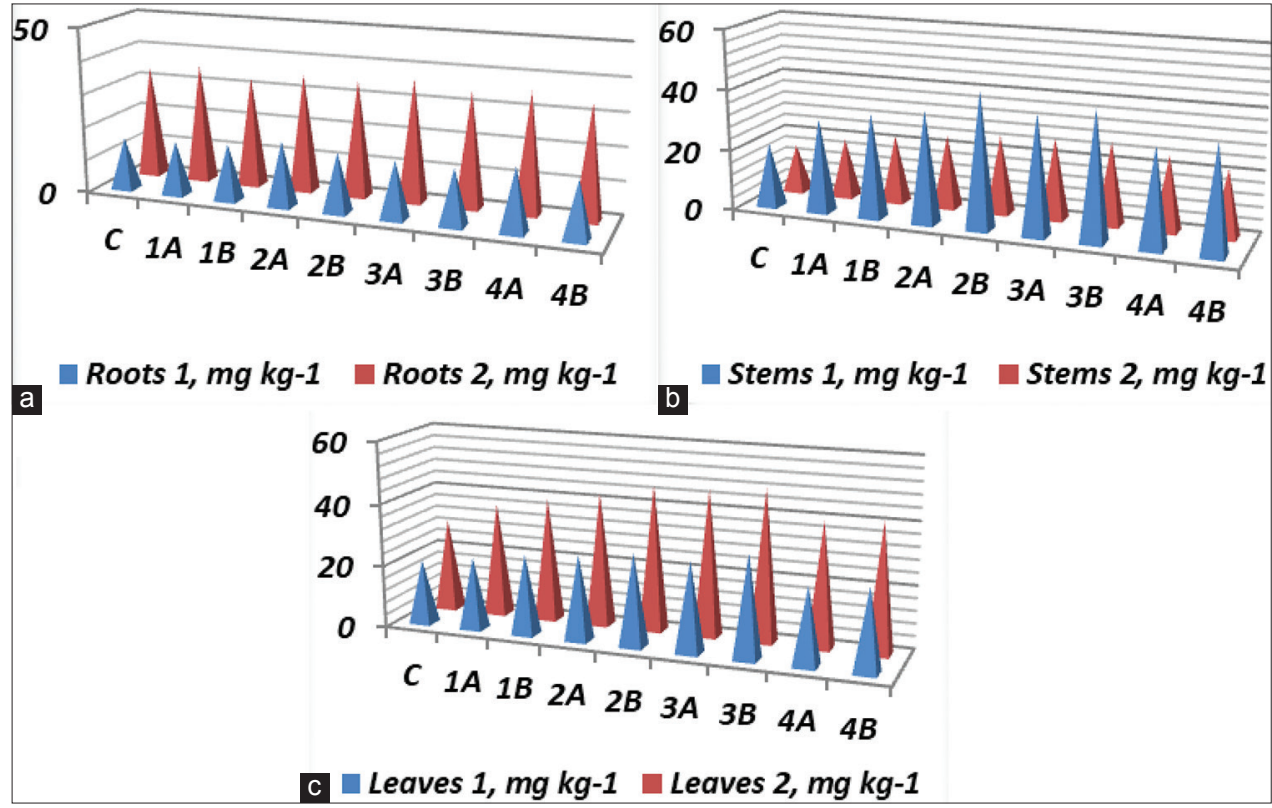

Fig 3. Concentration of $\mathrm{Zn}$ in the roots (a), stems (b) and leaves (c) three weeks after the first spraying and three weeks after the second spraying.

variant $1 \mathrm{~B}$ to $36.75 \mathrm{mg} \mathrm{kg}^{-1}$ in variant $3 \mathrm{~A}$. Conversely, the content of zinc in the stems decreased considerably in both the control sample and the variants. However, the statistically significant difference between the control and the variants remained. In the leaves, as well as in the roots, the content of zinc increased significantly, and the statistically significant difference between the control sample and the variants remained. The effect of different levels of Zn fertilization (350 and $700 \mathrm{~g} \mathrm{ha}^{-1}$ ) on the root, stem and leaf zinc concentrations remained insignificant.

To more clearly understand zinc uptake and its transport to the maize organs, the results obtained three weeks after the first spraying and three weeks after the second spraying were compared (Fig. 3). 
Fig. 3a shows that the zinc concentration of the plant roots increased in the same manner over the entire investigated growth period. The lack of a statistically significant difference between the root zinc content in the control and the variants suggests that the entire amount of zinc in the roots is absorbed by the soil solution. The results for the zinc content in the leaves were similar to those in the roots; its concentration increased substantially both in control and in all the variants (Fig. 3c). These results show that zinc does not move from the leaves to the roots and are in agreement with the results of Webb and Loneragan (1990) but contradict the results of other authors. Haslet et al. (2001) investigated the mobility of zinc in wheat by using labelled atoms (isotope ${ }^{68} \mathrm{Zn}$ ) and established that the transport of zinc in the phloem from the leaves to the lower leaves, stems and roots is substantial.

Fig. 3b shows completely different results for the two sprayings for the accumulation and transport of zinc in the stems. The first spraying resulted in a high concentration of $\mathrm{Zn}$ in the stems. Regardless of the additional amount of zinc deposited by the second spraying, the contents both in the control and in the variants decreased by almost 2 fold. Apparently, in the initial period of growth, the stems act as reservoirs in which the zinc that the plant needs in the next stages of its growth accumulates. This suggestion is in agreement with the results of other authors. Pearson and Rengel (1994) have studied the absorption of zinc by wheat and have found that zinc accumulates in the stems of plants and is readily remobilized to other parts of the plants in case of a diminished external supply. It seems that the transport of zinc in maize organs strongly depends on the growth period. During the first growth period, zinc movement is directed from the roots and leaves to the stem; then, the trend is reversed - the zinc that accumulated in the stem moves to other organs in the plant.

The expected result from fertilization is that the yield will increase and the quality of the resulting product will be improved. The results on the impact of $\mathrm{Zn}$ application on crop yield and quality are contradictory. Cakmak (2009) claimed that enriching fertilizers with $\mathrm{Zn}$ is an excellent tool for both crop production and biofortification of cereal grains with Zn. Kaiser, et al. (2016) concluded that "Foliar applications of zinc is not effective in correcting deficiencies of zinc. This method of application should be used on a trial basis only". Our study showed that treatment with $\mathrm{ZnHN}$ has positive effects on the yield and on the qualitative parameters of the corn. The results (Table 5) showed that plants fertilized with $\mathrm{ZnHN}$ had a significantly increased grain yield. The difference in the yield between the control and the yield of the variants ranged from 6.04 to $23.19 \%$ (mean $12.12 \%$ for the first group and $15.88 \%$ for the second group). The effect of different levels of $\mathrm{Zn}$ fertilization (350 and $\left.700 \mathrm{~g} \mathrm{ha}^{-1}\right)$ on the grain yield was significant $(\mathrm{p}<$ 0.05 ), and the yield of variant 3 was highest in both groups
$\left(\mathrm{ZnHN}\right.$ suspension $\left.+\mathrm{Zn}\left(\mathrm{NO}_{3}\right)_{2}\right)$. The addition of organic matter to the $\mathrm{ZnHN}$ suspension did not lead to higher yields compared to those of the pure $\mathrm{ZnHN}$ variants. More investigations are needed to estimate the effect of the simultaneous application of $\mathrm{ZnHN}$ and other nutrients.

Zinc is an essential micronutrient for protein production in plants and has a chemical and biological interaction with some other elements. The data in Table 6 show increased protein (respectively nitrogen) content in the grains of up to $25.9 \%$ for variant $4 \mathrm{~A}$ (average for all variants $16.7 \%$ ). In contrast, the starch content in all variants decreased by up to $9.4 \%$ for variant $3 \mathrm{~B}$ (average for all variants $5.2 \%$ ) compared with that of the control. These results imply that maize required additional zinc to attain its full yield potential.

No visible differences in the dry matter, fat and phosphorus content in the control and variants were observed, while the potassium content significantly decreased from 0.31 in the control to 0.26 in both variant groups. The effect of different levels of $\mathrm{Zn}$ fertilization (350 and $700 \mathrm{~g} \mathrm{ha}^{-1}$ ) on the grain structural components was insignificant.

The data in Table 7 show the specific impact of $\mathrm{ZnHN}$ application on the content of corn grain microelements. The absorption of zinc by plants strongly depends on soil acidity. Soils with a high $\mathrm{pH}$ and high phosphorus content reduce the mobility of the elements, which often leads to deficiencies in food. The results from Table 1 show that the soil of this research area is alluvial with a highly alkaline $\mathrm{pH}(8.20)$ and a low to medium zinc content, which implies that there would be problems with the absorption of the zinc contained in the soil. An alternative way to solve the problem of microelement availability and its deficiency in food is biofortification by using foliar fertilizers. Many positive results have been seen with foliar fertilizers, as noted above. In our experiment, the content of zinc and copper in the maize grains (Table 7) varied within narrow ranges (from 17.46 to $19.20 \mathrm{mg} \mathrm{kg}^{-1}$ for zinc and 1.30 to $1.85 \mathrm{mg} \mathrm{kg}^{-1}$ for copper). For both elements, there was no statistically significant difference between the control sample and the variants at a significance level of $p<0.05$. Our results contradict the results of other authors (Imran and Rehim, 2017). Multiple repetitions of the analyses exclude the possibility of sample inhomogeneity or inaccurate analytical results and imply that the maize genotype plays an essential role in biofortification. The trends in the magnesium content were similar to those for $\mathrm{Zn}$ and $\mathrm{Cu}$. Statistically significant differences between the control sample and the two groups of variants were found only for iron, which is in line with the understanding that $\mathrm{Zn}$ application has an adverse effect on the Fe concentration in plant tissues. The Fe content varied within a broad range of 6.70 in variant $3 \mathrm{~A}$ to $20.41 \mathrm{mg} \mathrm{kg}^{-1}$ in the control sample (mean of $9.30 \mathrm{mg} \mathrm{kg}^{-1}$ for the variants of the first group and $9.41 \mathrm{mg}$ $\mathrm{kg}^{-1}$ for the variants of the second group). 
The level of $\mathrm{Zn}$ fertilization (350 and $700 \mathrm{~g} \mathrm{ha}^{-1}$ ) did not affect the content of $\mathrm{Zn}, \mathrm{Cu}$ and $\mathrm{Fe}$ in the maize grain, while for $\mathrm{Mg}$, the difference between both groups of variants was significant at $\mathrm{p}<0.05$.

\section{CONCLUSIONS}

Based on the results presented, we can conclude that the synthesized zinc hydroxy nitrate has potential as a longterm foliar fertilizer. A significant $(\mathrm{p}<0.05)$ effect on $\mathrm{Zn}$ accumulation in the maize stems and leaves by foliar zinc application during the first growth stage was found. The accumulation of zinc was followed by its remobilization from the stems to other plant organs during the second growth stage. Ensuring the optimal concentration of $\mathrm{Zn}$ at different times during the vegetative period lead to a substantial increase in the grain yield along with an improvement in the quality of the corn grain for all variants compared to those of the control. More investigations are needed to develop the potential of nanosized zinc hydroxy nitrate as a foliar fertilizer. Further attention should be directed to improving its adhesion to the leaf surface as well as to the possibilities for its simultaneous application with other nutrients.

\section{ACKNOWLEDGEMENT}

This work was supported by the Agricultural University Science Fund (Project 14/18).

\section{Author contributions}

Conceptualization: KI and NN; methodology: KI, NN and TT; supervision of experiments: KI and T'T; data analysis: $\mathrm{AP}$ and AM; writing - original draft preparation: $\mathrm{KI}$, TT and AM; writing - review and editing: KI, TT, AM, AP and $\mathrm{NN}$; funding acquisition: TT. All authors read and approved the final manuscript.

\section{REFERENCES}

Alloway, B. J. 2008. Zinc in Soils and crop nutrition. $2^{\text {nd }}$ ed. IZA and IFA, Brussels, Belgium and Paris, France.

Cakmak, I. 2009. Enrichment of fertilizers with zinc: An excellent investment for humanity and crop production in India. J. Trace Elem. Med. Biol. 23(4): 281-289.

Fageria, N., M. Filho, A. Moreira and C. Guimarães. 2009. Foliar fertilization of crop plants. J. Plant Nutr. 32(6): 1044-1064.

Fernánez, V., T. Sotiropoulos and P. Brown. 2013. Foliar Fertilization: Scientific Principles and Field Practices. International Fertilizer Industry Association (IFA), Paris, France.

Haslett, B., R. Reid and Z. Rengel. 2001. Zinc mobility in wheat: Uptake and distribution of zinc applied to leaves or roots. Ann.
Bot. London. 87(3): 379-386.

Ivanov, K., E. Kolentsova, N. Nguyen, A. Peltekov and V. Angelova. 2017. Synthesis and stability of zinc hydroxide nitrate nanoparticles. Bulg. Chem. Commun. 49: 225-230.

Imran, M. and A. Rehim. 2017. Zinc fertilization approaches for agronomic biofortification and estimated human bioavailability of zinc in maize grain. Arch. Agron. Soil Sci. 63(1): 106-116.

Kaiser, D. E., C. J. Rosen and J. L. Lamb. 2016. Zinc for Crop Production, Nutrient Management, University of Minnesota Extension. Available from: https://www.extension.umn.edu/ micro-and-secondary-macronutrients/zinc-crop-production.

Kanwal, S., A. Rahmatullah and R. Ahmad. 2010. Zinc partitioning in maize grain after soil fertilization with zinc sulphate. Int. J. Agric. Biol. 12(2): 299-302.

Li, P., L. Li, Y. Du, M. Hampton, A. Nguyen, L. Huang and Z. Xu. 2014. Potential foliar fertilizers with copper and zinc dual micronutrients in nanocrystal suspension. J. Nanopart. Res. 16(11): 1-11.

Li, P., Y. Du, L. Huang, N. Mitter and Z. Xu. 2016. Nanotechnology promotes the R\&D of new-generation micronutrient foliar fertilizers. RSC Adv. 6(73): 69465-69478.

Li, P., Z. Xu, M. Hampton, D. Vu, L. Huang, V. Rudolph and A. Nguyen. 2012. Control preparation of zinc hydroxide nitrate nanocrystals and examination of the chemical and structural stability. J. Phys. Chem. C. 116(18): 10325-10332.

Marschner, H. 1997. Mineral Nutrition of Higher Plants. Academic Press, London, p. 889.

Newman, S. and W. Jones. 1999. Comparative study of some layered hydroxide salts containing exchangeable interlayer anions. J. Solid State Chem. 148(1): 26-40.

Papadopoulos, F., C. Prochaska, A. K. Papadopoulos, K. Eskridg and I. Kalavrouziotis. 2009. Mn and Zn micronutrients concentrations in acidic soils and source identification using multivariate statistical methods. Commun. Soil Sci. Plant Anal. 40(15-16): 2357-2371.

Pearson, J. and Z. Rengel. 1994. Distribution and remobilization of Zn and $\mathrm{Mn}$ during grain development in wheat. J. Exp. Bot. 45(12): 1829-1835.

Queiro, V., P. Guimarães, L. Queiroz, E. Guedes, E. Vasconcelos, V. Guimarães, P. Riberio and R. Schaffert. 2011. Iron and zinc availability in maize lines. Food Sci. Tech. Brasil. 31(3): 577-583.

Sadeghzadeh, B. 2013. A review of zinc nutrition and plant breeding. J. Soil Sci. Plant Nut. 13(4): 905-927.

Singh, N., N. Amist, K. Yadav, D. Singh, J. Pandey and S. Singh. 2013. Zinc oxide nanoparticles as fertilizer for the germination, growth and metabolism of vegetable crops. J. Nanoeng. Nanomanuf. 3(4): 353-364.

Vu, D., L. Huang, A. Nguyen, Z. Du, Z. Xu, M. Hampton and V. Rudolph. 2013. Quantitative methods for estimating foliar uptake of zinc from suspension-based $\mathrm{Zn}$ chemicals. J. Plant Nutr. Soil Sci. 176(5): 764-775.

Webb, M. and J. Loneragan. 1990. Zinc translocation to wheat roots and its implications for a phosphorus/zinc interaction in wheat plants. J. Plant Nutr. 13(12): 1499-1512.

Zou, C., Y. Zhang, A. Rashid, H. Ram, E. Savasli, R. Arisoy, I. OrtizMonasterio, S. Simunji, Z. H. Wang, V. Sohu, R. S. Freitas, R. S. Bal, S. S. Malik, J. Guo, I. Cakmak and B. Rerkasem. 2012. Biofortification of wheat with zinc through zinc fertilization in seven countries. Plant Soil. 361(1-2): 119-130. 